\title{
Synthesis and characterization of three new organo-selenium compounds. A convenient synthesis of aroylselenoglycolic acids
}

\author{
Petrônio Filgueiras de Athayde-Filho, ${ }^{* a, b, c}$ Antônio Gouveia de Souza, ${ }^{a}$ Soraya Alves de \\ Morais, ${ }^{a}$ José Regis Botelho, ${ }^{a}$ José Maria Barbosa-Filho, ${ }^{b}$ Joseph Miller, ${ }^{a, b, c}$ and \\ Bruno Freitas Lira ${ }^{b, c}$ \\ ${ }^{a}$ Universidade Federal da Paraíba Departamento de Química-CCEN, 58.081-970, João \\ Pessoa, PB, Brazil, ${ }^{b}$ Universidade Federal da Paraíba, Laboratório de Tecnologia \\ Farmacêutica, 58.081-970, João Pessoa, PB, Brazil, and ${ }^{c}$ Universidade Federal de \\ Pernambuco, Departamento de Química Fundamental, 50.570-901, Recife, PE, Brazil \\ E-mail: athayde-filho@bol.com.br
}

\section{Dedicated to Prof. Otto Richard Gottlieb}

(received 28 Jan 04; accepted 12 May 04; published on the web 14 May 04)

\begin{abstract}
A convenient one-pot three stage synthesis has been developed and used for obtaining three new aroylselenoglycolic acids. In the first stage powdered grey selenium reacts with $\mathrm{NaBH}_{4}$ in aqueous solution to form NaHSe. This reacts with selected aroyl chlorides to form sodium aroylselenides. In the third stage these react with $\alpha$-chloroacetic acid to form the desired aroylselenoglycolic acids. They were characterized by IR, ${ }^{1} \mathrm{H}$ and ${ }^{13} \mathrm{C}$ NMR spectrometry and by Elemental Analysis.
\end{abstract}

Keywords: Organo-selenium, one-pot synthesis, aroylselenoglycolic acids

\section{Introduction}

The structures of organo-selenium compounds are mentioned in the literature as being similar to those of organo-sulphur compounds, but their properties present significant differences. Because of their toxicity and their extremely unpleasant odour organo-selenium compounds have been relatively little explored. Organo-selenium compounds have been tested as antibacterial, antiviral, antifungal, antiparasitic, anti-inflammatory, antihistamine and anticancer agents. ${ }^{1}$

A method used to introduce selenium into organic molecules consists basically of converting carbonyl to selenocarbonyl groups using $\mathrm{P}_{2} \mathrm{Se}_{5}{ }^{2}$ Other methods substitute chloro by selenium in several classes of halogen compounds, e.g, $\mathrm{N}$-phenylbenzoimidoyl chloride, ${ }^{3}$ aroyl chlorides or dichloroisocyanate. ${ }^{5,6}$ Another method reacts alcohols with phosphorus pentaselenede to obtain 
dialkyldiselenophosphoric acids. ${ }^{7}$ Selenoureas can be obtained from thioureas or $S$ methylthiopseudoureas by reaction with hydroselenide ion. ${ }^{8}$ Yet, another convenient method to introduce selenium into organic molecules uses sodium hydrogen selenide with sodium borohydride in protonic solvents. ${ }^{9}$ In normal atmospheric conditions, selenium reacts quickly, vigorously and isothermally with sodium borohydride in aqueous solution to produce sodium hydrogen selenide according to the stoichiometry of the equation below.

$$
4 \mathrm{NaBH}_{4}+2 \mathrm{Se}+7 \mathrm{H}_{2} \mathrm{O} \rightarrow 2 \mathrm{NaHSe}+\mathrm{Na}_{2} \mathrm{~B}_{4} \mathrm{O}_{7}+14 \mathrm{H}_{2}
$$

It is relevant that many derivatives of thioglycolic acid are obtained by the thiocarboxylic acid reaction with $\alpha$-halogenoacetic acids. The products of there reactions are intermediaries in the preparation of several heterocyclic derivatives e.g. of mesoionic compounds. ${ }^{10}$

\section{Results and Discussion}

In this paper we describe a previously unpublished one-pot three stage synthesis of aroylselenoglycolic acids. We have thus synthesized and characterized three new compounds, benzoylselenoglycolic acid (1), 4-chloro-benzoylselenoglycolic acid (2) and benzoyl- $\alpha$ phenylselenoglycolic acid (3).

The first stage produces sodium hydrogen selenide by the powdered grey selenium reaction with sodium borohydride in aqueous solution (vide supra).

In the second stage NaHSe react with aroyl chlorides forming sodium aroylselenides

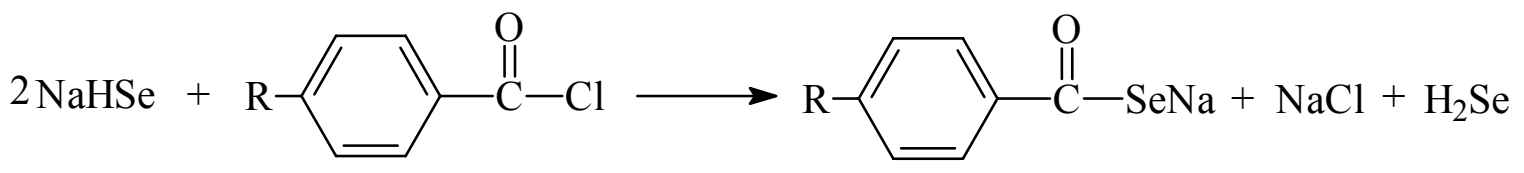

The third stage produces the aroylselenoglycolic acids by the reaction of the sodium aroyl selenides with $\alpha$-halogenoacetic acids.

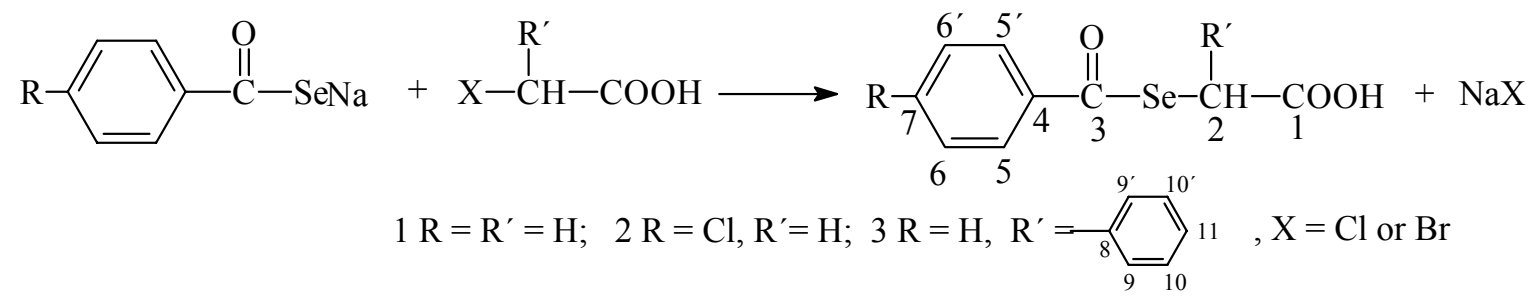

All the products gave satisfactory Elemental Analyses. The principal characteristic of the IR spectra is the $\mathrm{C}=\mathrm{O}$ stretch of the carbonyl and carboxyl groups at 1670 and 1701, 1682 and 1712, 1677 and 1702 for compounds 1,2 and 3 respectively. 
In the ${ }^{1} \mathrm{H}$ NMR spectra of compounds 1,2 and 3 the $\alpha$-hydrogen atoms have chemical shifts at $\delta=3.82,3.84$ and $5.49 \mathrm{ppm}$ respectively. The hydrogen atoms of the attached benzene ring have chemical shifts between 7.20 and $8.04 \mathrm{ppm}$. The hydrogen atoms of the acid group have chemical shifts around $10.50 \mathrm{ppm}$. For the ${ }^{13} \mathrm{C}$ NMR spectra the carbonyl group is characterized by a peak between 176 and 177 ppm and the carboxyl group has chemical shifts between 190 and $192 \mathrm{ppm}$. The $\alpha$-carbon is characterized by peaks at 24.8, 25.2 and 46.4 for compounds 1,2 and 3 respectively. Specifically for 2 the chemical shift at $140.1 \mathrm{ppm}$ indicates the chlorine atom linked to the aromatic ring in the para-position. The ${ }^{13} \mathrm{C}$ NMR chemical shifts of the new compounds are shown in Table 1.

Table 1. Chemical shifts in the ${ }^{13} \mathrm{C}$ NMR spectra of the new selenium derivatives (ppm)

\begin{tabular}{cccccccccccc}
\hline Comp & C1 & C2 & C3 & C4 & C5 & C6 & C7 & C8 & C9 & C10 & C11 \\
\hline 1 & 176.5 & 24.9 & 192.1 & 137.5 & 129.6 & 127.9 & 134.2 & - & - & - & - \\
2 & 176.4 & 25.8 & 191.0 & 136.1 & 129.3 & 128.6 & 140.7 & & & & \\
3 & 177.2 & 46.4 & 192.8 & 137.7 & 128.9 & 127.31 & 134.2 & 135.4 & 128.8 & 128.7 & 128.1 \\
\hline
\end{tabular}

\section{Conclusions}

A convenient methodology was used for the preparation of three aroylselenoglycolic acids. It was not necessary to isolate intermediates and this avoided problems of unpleasant odours and toxic residues.

\section{Experimental Section}

General Procedures. IR spectra were obtained on a Bruker IFS66 spectrometer. ${ }^{1} \mathrm{H}$ and ${ }^{13} \mathrm{C}$ NMR spectra were obtained on a Varian Mercury $200 \mathrm{MHz}$ NMR spectrometer with TMS as reference compound. Elemental Analyses were obtained on a Perkin Elmer Elemental Microanalyser. Melting points were determined on a Kofler hot-plate apparatus combined with a Carl Zeiss microscope and are uncorrected.

\section{General procedure for preparation of aroylselenoglycolic acids $\mathbf{1}$ - 3}

An aqueous solution of sodium borohydride was added with magnetic stirring at room temperature to powdered grey selenium suspended in distilled water. Within a few minutes a considerable amount of $\mathrm{H}_{2}$ was liberated and the selenium was consumed in approximately 5 minutes. The almost colourless solution of NaHSe which resulted was used without further treatment. The aroyl chloride was added and magnetically stirred for 1 hour. A yellow solution was formed and shortly thereafter an $\alpha$-halogenoacetic acid was added, in small portions. Within 
a few minutes white solid precipitates were formed. The products were filtered off, washed with distilled water, dried at reduced pressure then recrystallized from chloroform..

Benzoylselenoglycolic acid (1). Sodium borohydride $(1.0 \mathrm{~g}, 26.5 \mathrm{mmol})$ in $12.5 \mathrm{ml}$ of water, selenium grey powder $(1.0 \mathrm{~g}, 12.7 \mathrm{mmol})$ in $12.5 \mathrm{ml}$ of water, benzoyl chloride $(1.8 \mathrm{~g}$, $12.6 \mathrm{mmol})$ and $\alpha$-chloroacetic acid (1.2 g, $12.6 \mathrm{mmol})$ were used. The title compound $\mathbf{1}(2.0 \mathrm{~g})$ was obtained in $65 \%$ yield (in relation to the selenium) as white crystals. After recrystallization from chloroform it had $\mathrm{mp} 83-84{ }^{\circ} \mathrm{C}$. IR $v_{\max }(\mathrm{KBr}) \mathrm{cm}^{-1}: 3433,1701(-\mathrm{COOH}), 1679(-\mathrm{Se}-\mathrm{CO}-)$; ${ }^{1} \mathrm{H}$ NMR $\left(200 \mathrm{MHz}, \mathrm{CDCl}_{3}\right) \delta: 3.83(\mathrm{~s}, 2 \mathrm{H}), 7.39-8.00$ (m, 5H aromatic), $10.28(\mathrm{~s}, 1 \mathrm{H}$ carboxylic acid); $\left.{ }^{13} \mathrm{C} \mathrm{NMR} \mathrm{(50} \mathrm{MHz,} \mathrm{CDCl}_{3}\right) \delta: 24.9,127.3,128.9,134.2$, 137.6, 176.5, 192.1; Elemental Anal. Calcd for $\mathrm{C}_{9} \mathrm{H}_{8} \mathrm{O}_{3} \mathrm{Se}: \mathrm{C}, 44.46 ; \mathrm{H}, 3.32$. Found: $\mathrm{C}, 44.42 ; \mathrm{H}, 3.33 \%$.

4-Chlorobenzoylselenoglycolic acid (2). Sodium borohydride (1.0 g, $26.5 \mathrm{mmol})$ in $12.5 \mathrm{ml}$ of water, selenium grey powder $(1.0 \mathrm{~g}, 12.7 \mathrm{mmol})$ in $12.5 \mathrm{ml}$ of water, 4-chlorobenzoyl chloride (2.2 $\mathrm{g}, 12.6 \mathrm{mmol})$ and $\alpha$-chloroacetic acid $(1.2 \mathrm{~g}, 12.6 \mathrm{mmol})$ were used. The title compound 2 $(2,5 \mathrm{~g})$ was obtained in $71 \%$ yield (in relation to the selenium) as white crystals. After recrystallization from chloroform it had $\mathrm{mp} 135-136{ }^{\circ} \mathrm{C}$. IR $v_{\max }(\mathrm{KBr}) \mathrm{cm}^{-1}$ : 3439, $1712(-$ $\mathrm{COOH}), 1686(-\mathrm{Se}-\mathrm{CO}-)$; ${ }^{1} \mathrm{H}$ NMR $\left(200 \mathrm{MHz}, \mathrm{CDCl}_{3}\right) \delta: 3.84$ (s, 2H), 7.43 (d, 2H aromatic, $J=$ $8.0 \mathrm{~Hz}), 7.80(\mathrm{~d}, 2 \mathrm{H}$ aromatic, $J=8.0 \mathrm{~Hz}), 10.71\left(\mathrm{~s}, 1 \mathrm{H}\right.$ carboxylic acid); ${ }^{13} \mathrm{C} \mathrm{NMR}(50 \mathrm{MHz}$, $\left.\mathrm{CDCl}_{3}\right) \delta$ : 25.2, 128.6, 128.8, 136.1, 140.7, 176.3, 191.0; Elemental Anal. Calcd for $\mathrm{C}_{9} \mathrm{H}_{7} \mathrm{ClO}_{3} \mathrm{Se}: \mathrm{C}, 38.94 ; \mathrm{H}, 2.54$. Found: C, 38.92; H, $2.53 \%$.

Benzoyl-a-phenylselenoglycolic acid (3). Sodium borohydride (1.0 g, $26.5 \mathrm{mmol})$ in $12.5 \mathrm{ml}$ of water, selenium grey powder $(1.0 \mathrm{~g}, 12.7 \mathrm{mmol})$ in $12.5 \mathrm{ml}$ of water, benzoyl chloride $(1.8 \mathrm{~g}$, $12.6 \mathrm{mmol})$ and $\alpha$-bromophenylacetic acid (2.7 g, $12.6 \mathrm{mmol})$ were used. The title compound 3 $(2.8 \mathrm{~g})$ was obtained in $69 \%$ yield (in relation to the selenium) as white crystals. After recrystallization from chloroform it had $\mathrm{mp} 115-116^{\circ} \mathrm{C}$. IR $v_{\max }(\mathrm{KBr}) \mathrm{cm}^{-1}$. 3426, 1702($\mathrm{COOH}), 1677(-\mathrm{Se}-\mathrm{CO}-)$; ${ }^{1} \mathrm{H} \mathrm{NMR}\left(200 \mathrm{MHz}, \mathrm{CDCl}_{3}\right) \delta: 5.50$ (s, 1H), 7.30-7.6 (m, $10 \mathrm{H}$ aromatic), 10.55 (s, $1 \mathrm{H}$ carboxylic acid); ${ }^{13} \mathrm{C} \mathrm{NMR}\left(50 \mathrm{MHz}, \mathrm{CDCl}_{3}\right) \delta: 25.2,128.6,128.8$, 136.1, 140.7, 176.3, 191.0;:Elemental Anal. Calcd for $\mathrm{C}_{15} \mathrm{H}_{12} \mathrm{O}_{3} \mathrm{Se}$ : C, 56,44; H, 3.79. Found: C, $56.45 ; \mathrm{H}, 3.75 \%$.

\section{Acknowledgements}

The authors thank the Brazilian National Research Council $(\mathrm{CNPq})$ for a research grant.

\section{References}

1. Shamberger R.J. Biochemistry of Selenium; Frieden, E., Ed.; Plenum Press; 1983, Ch. 7.

2. Van den Hende, H.; Klingsberg, E. J. Amer. Chem. Soc. 1966, 88, 5045.

3. Cava, M. P.; Saris L.A. J. Chem. Soc. Chem. Comm. 1975, 617. 
4. Douglas, I. B. J. Amer. Chem. Soc. 1937, 59, 741.

5. Stolte, H. Ber. 1886, 19, 2350.

6. Hasan, C.; Hunter, R. J. Chem. Soc. 1935, 1762.

7. Kudchadker, M. V.; Zingaro, R. A.; Irgolic, K. J. Can. J. Chem. 1968, 46,1415.

8. Klayman, D. L.; Shine, R. J. J. Org. Chem. 1969, 34, 3548.

9. Klayman, D. L.; Griffin, T. S. J. Amer. Chem. Soc. 1973, 95, 197.

10. Masuda, K.; Adachi, J.; Nomura, K. Chem. Pharm. Bull. 1977, 25, 1471. 